\title{
報文
}

\section{有機ベントナイト配合塗料の研究（第 $\mathbf{2}$ 報）* UDC}

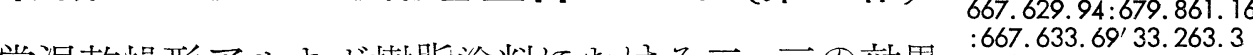
常温乾燥形アルキド樹脂塗料における二, 三の効果 : 678.674

Studies on paint containing organophilic bentonite. II.

Some effects on air-drying alkyd resin paint

$$
\begin{aligned}
& \text { 近藤三二林・金口年 男 }{ }^{* *} \\
& \text { Kondô Mitsuzi Kanaguti Tosio }
\end{aligned}
$$

要旨

常温乾燥形アルキド樹脂叙料に和ける有機ベントナイトの配合効果を，コンシステ ンシー, 八ヶ別き, タルミ, 顔料沈殿, 乾燥時間, 而屈曲性叔よび耐候性について検 討した。その結果, 有機ベントナイトは

（1）八ケ唰きを重くすることなく見掛け粘度を增大し塗料のコンシステンシーを

向上させる。

（2）塗料のコンシステンシー経時変化を小さくし安定化する。

（3）すぐれたタルミ防止効果を示す。これは主としてその增粘作用に基づくが, さらに有機ベントナイトの板状粒子が膜面と平行に配列し膜面方向のずれを拘束して タルミ防止に寄与することが推定された。

（4）顔料沈降容磧を大きくし，再分散しやすい膨潤した顔料層を形成させるので 顔料沈降防止剂としてもすぐれている。

（5）乾燥塗膜の耐屈曲性を幾分高的る。

（6）乾燥時間および耐候性にほとんど影響を及ぼさない。

\section{1. 緒言}

著者らは先きに有機ベントナイトを含む塗料ビヒクル 系は，有機ベントナイトがビヒクルと溶媒和しチクソト ロピックな塑性流動性質を顕著化示すことから，流れ止 剂や顔料沈降防止剤など塗料の流動性質を改良する目的 に応用し得ることを示唆 ${ }^{1,2}$ したが, 本報では塗料の作業 性に及洔す有機ベントナイトの影響について具体的なデ 一タを得るため, 常温乾燥形アルキド樹脂塗料を選びそ の乾燥速度, コンシステンシー, タルミ括よび顔料沈降 性沉及济す配合効果总従来これらの目的に用いられてい るステアリン酸アルミニウム括よび微粉無水ケイ酸の配 合効果々比較検討した。な就これら流れ止剂配合塗膜の 耐候性おっび耐屈曲性についてる試験した。

\section{2. 実験および考察}

\footnotetext{
昭 38. 12. 23 受理

* 第 1 報 本誌 -36 [ 5 ] 217 224（1963）

** 白石工業 (株) 本社研究所
}

\section{1. 試 料}

各種流礼止剤の一般性質を゙、表-1と示す。またその他 の顔料, ビヒクル，溶剤和よびドライヤーは市販品をそ のまま使用した。

\begin{tabular}{|c|c|c|c|c|}
\hline & $\begin{array}{c}\text { 有機ベン } \\
\text { トナイト } \\
\text { (I) }\end{array}$ & $\begin{array}{c}\text { 有機ベン } \\
\text { トナイト } \\
\text { (II) }\end{array}$ & $\begin{array}{l}\text { ステアリ } \\
\text { ン酸アル } \\
\text { ミニウム }\end{array}$ & $\begin{array}{l}\text { 微粉無水 } \\
\text { ケイ酸 }\end{array}$ \\
\hline 商 品 名 & オルベン & オルベン A & - & エロジール \\
\hline 化学組成 & $\begin{array}{l}\text { モンモリロ } \\
\text { ナイトの有 } \\
\text { 機複合体* }\end{array}$ & $\begin{array}{l}\text { モンモリロ } \\
\text { ナイトの有 } \\
\text { 機複合体* }\end{array}$ & $\begin{array}{l}\text { ジステアリ } \\
\text { ン酸アルミ } \\
\text { =ウム }\end{array}$ & $\mathrm{SiO}_{2}$ \\
\hline 形 状 & 微 粉 末 & 微 粉 末 & 微粉末 & 微 粉 末 \\
\hline 融点 $\left({ }^{\circ} \mathrm{C}\right)$ & ナ シ & ナ & $114 \sim 116$ & $ナ$ \\
\hline $\mathrm{pH}$ & 7.5 & 7.5 & 5.6 & 4.5 \\
\hline 粒 子径 & $\begin{array}{l}\text { 厚み } 20 \AA \\
\text { 径0.05 } \\
\quad \sim 1.0 \mu\end{array}$ & $\begin{array}{l}\text { 厚又 } 20 \AA \\
\text { 径 } 0.05 \\
\quad 1.0 \mu\end{array}$ & - & $\begin{array}{l}0.01 \sim \\
\quad 0.02 \mu\end{array}$ \\
\hline
\end{tabular}

表-1 各種流れ止剤の一般性質

\footnotetext{
*近似的㳄次式で表示する。 $\left[(\mathrm{OH})_{4} \mathrm{Si}_{8}\left(\left(\mathrm{Al}_{3.34} \mathrm{Mg}_{0.66}\right) \mathrm{O}_{20}\right] \cdot n\left[\mathrm{C}_{18} \mathrm{H}_{37} \mathrm{~N}^{+}\left(\mathrm{CH}_{3}\right)_{3}+\right.\right.$ $\left.\mathrm{C}_{17} \mathrm{H}_{35} \mathrm{CONH}_{2}\right]_{\text {complex }}$
} 


\section{2. 実験方法}

\section{1 流れ止剤の使用方法および塗料の調製方法}

磁製ボールミルに所定の配合となるよう顔料, 流れ止 剂，ビヒクル，溶剤およびドライヤーを仕込み40時間回 転させて塗料 $2.5 \sim 3 \mathrm{~kg}$ を調製した。流れ止剤の使用方 法は有機ベントナイトの場合のみあらかじめミネラルス ピリットと溶媒和させたプレゲルとして用い，その他の 流れ止剤は粉末のまま使用した。有機ベントナイト・プ
レゲルの調製方法は有機ベントナイト 20 部とミネラル スピリット 72 部をカキマゼてスラリーとなし, カキマ ゼを続けながらこれに溶媒和促進助剤としてアセトン 8 部(またはメタノールでもよい)を加えてゲル化させた。 以上の実験方法を図-1 に示す。得られた塗料は直らに 広口の $500 \mathrm{cc}$ ビンに入れ密栓して貯蔵し試験に供した。

\section{2 塗料の配合}

低 PVC の光沢エナメルに準ずる配合を塗料 A とし, 中 PVC の半光沢に準ずる配合 を塗料 B としてその組成を表-2 に示す。

\section{3 試験方法}

乾燥時間 : $150 \mathrm{~mm} \times 340 \mathrm{~mm}$ $\times 5 \mathrm{~mm}$ の磨きガラス板上に塗 料 $1 \mathrm{cc}$ を注射器を用いて取り
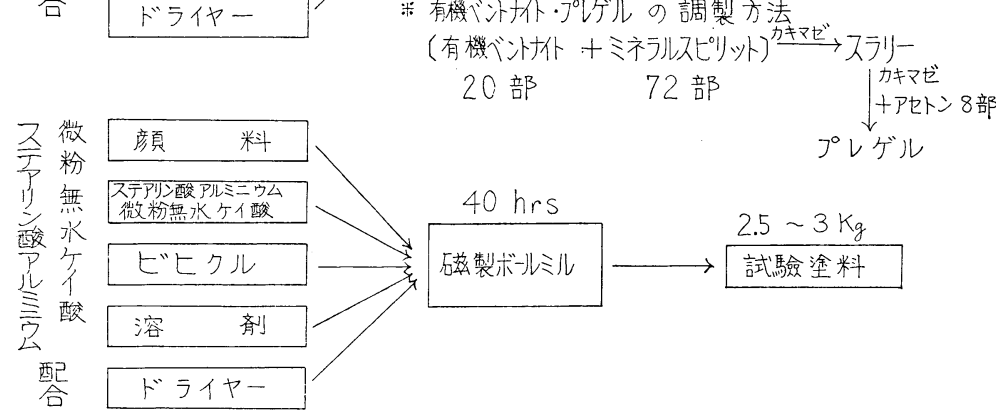

40 hrs

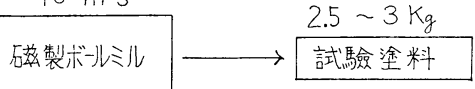

図-1＼cjkstart流れ止剤使用方法㘧よび塗料の調製方法

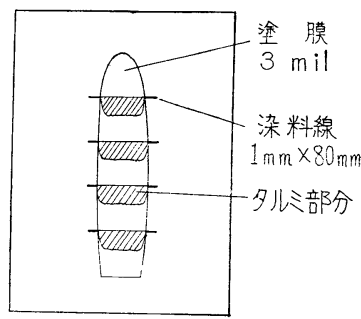

図-2 タルミ試験パネル略図
表-2 塗料配合の分類

\begin{tabular}{|c|c|c|}
\hline & A & B \\
\hline & 重量部 & 重量部 \\
\hline 酸化チタン(ルチル) & 220.0 & 183.0 \\
\hline 酸 化 亜 鉛 (1 号) & 30.0 & 25.0 \\
\hline 炭酸カルシウム(重質) & 一 & 236.0 \\
\hline 流 れ 止 凨 & 変量 $(0 \sim 10.0)$ & 变量 $(0 \sim 10.0)$ \\
\hline $\begin{array}{l}\text { 大豆変性長油アルキド } \\
\text { 樹脂* } \\
(70 \%)\end{array}$ & 472.0 & 394.0 \\
\hline ミネラルスピリット** & 216.7 & 152.5 \\
\hline テルペン 油 & 50.0 & - \\
\hline ナフテン酸 Co $(8 \%)$ & 3.1 & 2.6 \\
\hline ナフテン酸 $\mathrm{Pb}(20 \%)$ & 8.2 & 6.9 \\
\hline 合 & $\begin{array}{r}1,000.0 \sim \\
1,010.0\end{array}$ & $\begin{array}{r}1,000.0 \sim \\
1,010.0\end{array}$ \\
\hline $\begin{array}{l}\text { 固形分中の顔料容積濃 } \\
\text { 度 }(\%)\end{array}$ & 16 & 34 \\
\hline 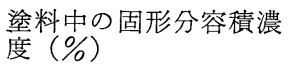 & 41 & 52 \\
\hline
\end{tabular}

* 大豆油 $65 \%$, 無水フタル酸 $24 \%$

**有機ベントナイト・プレゲル調製に用いた少量のア セトンはミネラルスピリットとして計算した。
アプリケーター $3 \mathrm{mil}$ を用いて塗膜をつくり指触法3に より set-to-touch, dried-hard 特よび dry-handle に 要する乾燥時間を測定した。

Krebs Unit) 上島製作所製 ストーマー粘度 計により 恒温槽中 $25 \pm 0.5^{\circ} \mathrm{C}$ に保つた試料について測定した。以 下 $\mathrm{KU}$ と略記する。

粘度 : 東京計器製作所製 B-M 形粘度計により $25 \pm$ $0.5^{\circ} \mathrm{C}$ に保った試料について見掛け粘度を測定した。

タルミ5)：試験パネルとして磨き黒曜石板 $(250 \mathrm{~mm} \times$ $340 \mathrm{~mm} \times 17 \mathrm{~mm}$ ）を用い，その表面を $\mathrm{n}$ 一ヘキサンで清 浄にし油溶性染料溶液 (補充用マジックインキ, 青色) をもって図-2 に示すように 4 本の青色線を画き, 3 分 間放置して乾燥させたのちパネルを正しく水平に置く。 注射器を用いて塗料 $1.0 \mathrm{cc}$ をパネル上に取り，直ちに アプリケーター $3 \mathrm{mil}$ を用いて塗膜を引く。 $0.4 \mathrm{~mm}$ 厚 みのパッキングを周囲に張ったガラス板でシールし 90 秒間放置したのち垂直に保ち 10 分間放置する。タルミ の読みはパネル上の染料線下端から塗膜に移った染料線 の下端までの長さ $(\mathrm{mm})$ を測定する。別に水平位置で 10 分間放置した場合の染料線の広がりからニジミを測定し 
表-3 タルミ試験に用いるパネルの比較

\begin{tabular}{|c|c|c|c|c|c|c|}
\hline \multirow{2}{*}{ パネル } & \multirow{2}{*}{$\begin{array}{l}\text { 実験 } \\
\text { No. }\end{array}$} & \multicolumn{5}{|c|}{ タルミ $(\mathrm{mm} / 10$ 分, $3 \mathrm{mil})$} \\
\hline & & 1 & 2 & 3 & 4 & 平均 \\
\hline \multirow{3}{*}{ 並ガラス板 } & 1 & 16 & 16 & 23 & 13 & - \\
\hline & 2 & 54 & 50 & 36 & 18 & - \\
\hline & 3 & 42 & 43 & 50 & 42 & - \\
\hline \multirow{3}{*}{ 磨 き黒矅 } & 1 & 11 & 11 & 11 & 10 & 11 \\
\hline & 2 & 11 & 12 & 11 & 11 & 11 \\
\hline & 3 & 11 & 12 & 10 & 10 & 11 \\
\hline
\end{tabular}

タルミ測定值を補正した。本実験ではニジミはいずれも 約 $1 \mathrm{~mm}$ で女った。な搞本実験法による再現性は表-3の と拝りで表面の平滑な磨き黒㺟石板を試験パネルとして 用いることにより十分な精度の測定がなされることがわ かつた。並ガラス板では表面の凹凸のため信頼し得る結 果が得られない。

顔料沈降容積: 調製直後の試料 $500 \mathrm{cc}$ を直径 $80 \mathrm{~mm}$, 深さ $130 \mathrm{~mm}$ のガラスビンに入れ 密栓して暗所に静置 し 90 日後の顔料層の容積を測定した。

促進耐候試験： $200 \mathrm{~mm} \times 50 \mathrm{~mm} \times 1 \mathrm{~mm}$ の冷間圧延鋼 板を 240 番研摩紙で磨き, ベンゼン・エタノール等量混 合液で洗浄したのち，市販の鉛丹ジンククロメートペイ ント（JIS K 5628）を2回ハケ塗りしてさび止を行い, この上に試料エナメルを 2 回ハケ塗りし， 5 日間乾燥し たのち次の条件で促進耐候試験を行なった。なお試験塗 料の乾燥塗膜の厚みは約 $0.1 \sim 0.13 \mathrm{~mm}$, 平均 $0.12 \mathrm{~mm}$ である。

装置東洋理化製自動万能老化試験機

光源 Twin arc

温度 $\quad 60 \pm 2^{\circ} \mathrm{C}$

人工降雨 120 分中 18 分降雨サイクル

時間 $\quad 1,000$ 時間

耐屈曲性：JIS K 5572 フタル酸樹脂エナメル抽よび JIS K5573 ッャ無しフタル酸樹脂エナメルの耐屈曲性試 験法に準じて行なった。

\section{3. 実験結果および考察}

\section{1 塗料中における 有機 ベントナイトとドライヤー との相互影響}

塗料のコンシステンシーに及ぼす有機ベントナイトの 効果が共存するドライヤーによつてどのような影響を受

表-5 塗料中に扔ける有機ベントナイトとドライヤーと

\begin{tabular}{|c|c|c|c|c|c|}
\hline \multirow[b]{2}{*}{ 塗料の種 類 } & \multicolumn{3}{|c|}{ 乾燥時間 (hrs) } & \multicolumn{2}{|c|}{$\begin{array}{l}\text { コンシス } \\
\text { テンシー }\end{array}$} \\
\hline & $\begin{array}{l}\text { set-to- } \\
\text { touch }\end{array}$ & $\begin{array}{l}\text { dried- } \\
\text { hard }\end{array}$ & $\begin{array}{l}\text { dry- } \\
\text { handle }\end{array}$ & $\mathrm{KU}$ & $\begin{array}{l}\text { 粘度 } \\
\mathrm{CPS} / \\
12 \mathrm{rpm}\end{array}$ \\
\hline 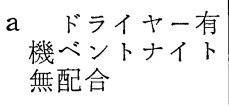 & - & - & - & 59 & 100 \\
\hline b $\mathrm{Co}-\mathrm{Pb}$ 配 合 & 2.0 & $2.5 \sim 3.0$ & 4.0 & 61 & 160 \\
\hline 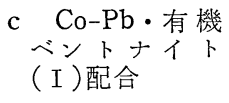 & 2.0 & $2.5 \sim 3.0$ & 4.0 & 62 & 300 \\
\hline 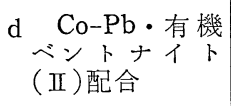 & 2.0 & $2.5 \sim 3.0$ & 4.0 & 61 & 290 \\
\hline e $\mathrm{Mn}-\mathrm{Pb}$ 配 合 & 2.5 & $3.5 \sim 4.0$ & 5.0 & 61 & 130 \\
\hline 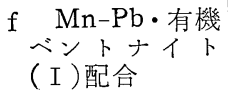 & 2.5 & $3.5 \sim 4.0$ & 5.0 & 61 & 250 \\
\hline $\begin{array}{l}\text { g } \mathrm{Mn}-\mathrm{Pb} \text { ・有機 } \\
\text { ベントナイト } \\
\text { (II)配合 }\end{array}$ & 2.5 & $3.5 \sim 4.0$ & 5.0 & 61 & 300 \\
\hline 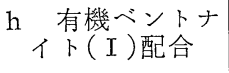 & - & - & - & 60 & 130 \\
\hline 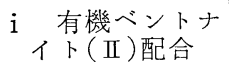 & - & - & - & 60 & 150 \\
\hline
\end{tabular}

表-4 塗料中に抢ける有機ベントナイトとドライヤーとの相互影響：試験塗料の配合（重量部）

\begin{tabular}{|c|c|c|c|c|c|c|c|c|c|}
\hline & a & $\mathrm{b}$ & $\mathrm{c}$ & $\mathrm{d}$ & e & $\mathrm{f}$ & $\mathrm{g}$ & $\mathrm{h}$ & $\mathrm{i}$ \\
\hline 酸 化 チ タン（ルチル） & 220.0 & 220.0 & 220.0 & 220.0 & 220.0 & 220.0 & 220.0 & 220.0 & 220.0 \\
\hline 酸 化 亜 鉛 ( 1 号) & 30.0 & 30.0 & 30.0 & 30.0 & 30.0 & 30.0 & 30.0 & 30.0 & 30.0 \\
\hline 有機ベントナイト（I） & - & - & 4.0 & - & - & 4.0 & - & 4.0 & 一 \\
\hline 有機ベントナイト（II） & - & 一 & - & 4.0 & 一 & - & 4.0 & - & 4.0 \\
\hline 大豆変性長油アルキド樹脂 $(70 \%)$ & 472.0 & 472.0 & 472.0 & 472.0 & 472.0 & 472.0 & 472.0 & 472.0 & 472.0 \\
\hline ミネラルスピリット & 216.7 & 216.7 & 216.7 & 216.7 & 216.7 & 216.7 & 216.7 & 216.7 & 216.7 \\
\hline テ ル ペ ン 油 & 50.0 & 50.0 & 50.0 & 50.0 & 50.0 & 50.0 & 50.0 & 50.0 & 50.0 \\
\hline ナフ テ ン 酸 $\mathrm{Co}(8 \%)$ & - & 3.1 & 3.1 & 3.1 & - & - & - & - & - \\
\hline ナ・フ テ ン 酸 $\mathrm{Mn}(4 \%)$ & - & - & - & - & 8.2 & 8.2 & 8.2 & - & - \\
\hline ナフテン酸 $\mathrm{Pb}(20 \%)$ & - & 8.2 & 8.2 & 8.2 & 8.2 & 8.2 & 8.2 & 一 & - \\
\hline
\end{tabular}

アルキド樹脂に対するドライヤー添加率 Co:0.075\%, $\mathrm{Mn}: 0.10 \%, \mathrm{~Pb}: 0.50 \%$

アルキド樹脂に対する有機ベントナイト添加率 $1.2 \%$ 
ケるか，またドライヤーの乾燥作用が有機ベントナイト によってどのように影響されるかについてまず検討する ことにした。ドライヤーとしては $\mathrm{Co}-\mathrm{Pb}$ 扣よび $\mathrm{Mn}-\mathrm{Pb}$ を選び, 表-2 に示した塗料 $\mathrm{A}$ を基礎として表-4 の配合 に示す各塗料の乾燥時間およびコンシステンシーを測定 した結果を表-5 に示す。

表-5 の結果からドライヤーのみ配合した塗 料の乾燥 時間とドライヤー拉よび有機ベントナイトの両者を含む 塗料の乾燥時間はほとんど一致しており，有機ベントナ イトはドライヤーの乾燥作用にほとんど影響を及ぼして いないものと考えられる。塗料のコンシステンシーにつ いて検討してみると，ドライヤー特よび有機ベントナイ トを添加せずに単に顔料だけをビヒクル中に分散させた 配合aでは $\mathrm{KU}$ 括よび粘度が最も低い值を示して扣り， ドライヤーを添加した配合 $\mathrm{b}$ 打よび $\mathrm{e}$ はいずれも $\mathrm{KU}$ 和 よび粘度が増大している。この原因としては报とらくボ ールミルにより 40 時間練和を行なった際に塗料中に空 気が混入しドライヤーの作用によってアルキド樹脂の重 合がある程度生じるためであろう。次にドライヤーを含 まない有機ベントナイトのみを添加した配合 h は、に比べて KU 拉よび粘度が増大していることは当然 である。そしてドライヤー和よび有機ベントナイトの両 者を添加した配合 $\mathrm{c}, \mathrm{d}, \mathrm{f}$ 特よび $\mathrm{g}$ は最も高いコンシス テンシー值を示しているが，ドライヤー配合塗料の粘度
$\left(\eta_{D}\right)$ に対するドライヤー・有機 ベントナイト配合塗料 の粘度 $\left(\eta_{D \cdot B t}\right)$ の相対值叔よびドライヤー・有機ベント ナイト無配合塗料の粘度 $\left(\eta_{0}\right)$ に対する有機ベントナイト

表-6 調製 1 日後のコンシステンシー測定結果

\begin{tabular}{l} 
流れ止剤配合率 \% \\
\cline { 3 - 6 }
\end{tabular}

表-7 塗料 B のコンシステンシー経時変化

\begin{tabular}{|c|c|c|c|c|c|c|c|c|c|c|c|c|c|}
\hline \multirow{2}{*}{\multicolumn{2}{|c|}{ 流れ止剤配合率 \% }} & \multicolumn{4}{|c|}{$\mathrm{KU}$} & \multicolumn{4}{|c|}{ 粘度 $\mathrm{cps} / 6 \mathrm{rpm}$} & \multicolumn{4}{|c|}{ 放置粘度/初期粘度比 } \\
\hline & & 1 日 & 10日 & 30 日 & 90 日 & 1 日 & 10日 & 30 日 & 90 日 & 1 日 & 10日 & 30 日 & 90 日 \\
\hline $\begin{array}{l}\text { ブランク（流小 } \\
\text { 無配合） }\end{array}$ & 止剤 & 75 & 80 & 80 & 80 & 800 & 1,020 & 1,220 & 1,340 & 1 & 1.28 & 1.53 & 1.68 \\
\hline $\begin{array}{l}\text { 有機ベントナ } \\
\text { イ }\end{array}$ & $\begin{array}{l}0.2 \\
0.4 \\
0.6 \\
0.8 \\
1.0\end{array}$ & $\begin{array}{l}77 \\
83 \\
85 \\
91 \\
93\end{array}$ & $\begin{array}{l}86 \\
87 \\
88 \\
94 \\
98\end{array}$ & $\begin{array}{l}88 \\
89 \\
90 \\
96 \\
99\end{array}$ & $\begin{array}{r}88 \\
89 \\
92 \\
96 \\
101\end{array}$ & $\begin{array}{l}1,360 \\
1,660 \\
2,100 \\
2,640 \\
3,080 \\
\end{array}$ & $\begin{array}{l}1,590 \\
1,920 \\
2,330 \\
3,110 \\
3,630\end{array}$ & $\begin{array}{l}1,960 \\
2,140 \\
2,760 \\
3,640 \\
4,660 \\
\end{array}$ & $\begin{array}{l}2,125 \\
2,500 \\
2,820 \\
3,620 \\
4,480 \\
\end{array}$ & $\begin{array}{l}1 \\
1 \\
1 \\
1 \\
1\end{array}$ & $\begin{array}{l}1.17 \\
1.16 \\
1.11 \\
1.18 \\
1.18\end{array}$ & $\begin{array}{l}1.44 \\
1.29 \\
1.32 \\
1.38 \\
1.51\end{array}$ & $\begin{array}{l}1.56 \\
1.50 \\
1.34 \\
1.37 \\
1.45\end{array}$ \\
\hline $\begin{array}{l}\text { 有機ベントナ } \\
\text { イ }\end{array}$ & $\begin{array}{l}0.2 \\
0.4 \\
0.6 \\
0.8 \\
1.0\end{array}$ & $\begin{array}{r}83 \\
85 \\
90 \\
94 \\
112\end{array}$ & $\begin{array}{r}83 \\
85 \\
90 \\
94 \\
112\end{array}$ & $\begin{array}{r}83 \\
86 \\
90 \\
94 \\
120\end{array}$ & $\begin{array}{r}86 \\
88 \\
89 \\
98 \\
117\end{array}$ & $\begin{array}{l}1,470 \\
1,870 \\
2,530 \\
3,430 \\
8,500\end{array}$ & $\begin{array}{r}1,640 \\
2,200 \\
3,160 \\
4,020 \\
11,240\end{array}$ & $\begin{array}{r}1,850 \\
3,040 \\
3,400 \\
4,760 \\
13,540\end{array}$ & $\begin{array}{r}2,340 \\
2,500 \\
3,600 \\
6,000 \\
15,100\end{array}$ & $\begin{array}{l}1 \\
1 \\
1 \\
1 \\
1\end{array}$ & $\begin{array}{l}1.12 \\
1.18 \\
1.25 \\
1.17 \\
1.32 \\
\end{array}$ & $\begin{array}{l}1.26 \\
1.63 \\
1.34 \\
1.39 \\
1.59\end{array}$ & $\begin{array}{l}1.59 \\
1.33 \\
1.42 \\
1.74 \\
1.77\end{array}$ \\
\hline $\begin{array}{l}\text { 微粉無水ケイ } \\
\text { 酸 }\end{array}$ & $\begin{array}{l}0.2 \\
0.4 \\
0.6 \\
0.8 \\
1.0\end{array}$ & $\begin{array}{l}79 \\
82 \\
82 \\
83 \\
83\end{array}$ & $\begin{array}{l}79 \\
82 \\
82 \\
83 \\
83\end{array}$ & $\begin{array}{l}83 \\
83 \\
83 \\
85 \\
86\end{array}$ & $\begin{array}{l}84 \\
84 \\
85 \\
85 \\
86\end{array}$ & $\begin{array}{l}1,140 \\
1,400 \\
1,600 \\
1,700 \\
2,000 \\
\end{array}$ & $\begin{array}{l}1,340 \\
1,760 \\
1,800 \\
1,960 \\
2,200\end{array}$ & $\begin{array}{l}1,560 \\
1,900 \\
2,100 \\
2,180 \\
2,540\end{array}$ & $\begin{array}{l}1,880 \\
2,000 \\
2,100 \\
2,220 \\
2,540\end{array}$ & $\begin{array}{l}1 \\
1 \\
1 \\
1 \\
1\end{array}$ & $\begin{array}{l}1.18 \\
1.26 \\
1.13 \\
1.15 \\
1.10\end{array}$ & $\begin{array}{l}1.37 \\
1.36 \\
1.31 \\
1.28 \\
1.27\end{array}$ & $\begin{array}{l}1.64 \\
1.42 \\
1.31 \\
1.30 \\
1.27\end{array}$ \\
\hline $\begin{array}{l}\text { ステアリン酸 } \\
\text { アルミニウム }\end{array}$ & $\begin{array}{l}0.2 \\
0.4 \\
0.6 \\
0.8 \\
1.0\end{array}$ & $\begin{array}{l}78 \\
78 \\
79 \\
81 \\
83\end{array}$ & $\begin{array}{l}81 \\
81 \\
83 \\
84 \\
89\end{array}$ & $\begin{array}{l}83 \\
83 \\
87 \\
88 \\
92\end{array}$ & $\begin{array}{l}86 \\
86 \\
90 \\
90 \\
92\end{array}$ & $\begin{array}{l}1,440 \\
1,520 \\
1,600 \\
1,660 \\
1,940\end{array}$ & $\begin{array}{l}2,040 \\
2,040 \\
2,660 \\
2,840 \\
3,440\end{array}$ & $\begin{array}{l}2,320 \\
2,320 \\
3,000 \\
3,600 \\
4,300\end{array}$ & $\begin{array}{l}2,100 \\
2,400 \\
3,200 \\
3,500 \\
4,000\end{array}$ & $\begin{array}{l}1 \\
1 \\
1 \\
1 \\
1\end{array}$ & $\begin{array}{l}1.42 \\
1.34 \\
1.66 \\
1.71 \\
1.77\end{array}$ & $\begin{array}{l}1.61 \\
1.53 \\
1.88 \\
2.17 \\
2.22\end{array}$ & $\begin{array}{l}1.45 \\
1.57 \\
2.00 \\
2.10 \\
2.06\end{array}$ \\
\hline
\end{tabular}


配合塗料の粘度 $\left(\eta_{B t}\right)$ の相対值を求め比較してみると次 のようになる。

$$
\begin{aligned}
& \eta_{D \cdot B t} / \eta_{D} \quad \eta_{B t} / \eta_{0} \\
& \mathrm{c} / \mathrm{b}=1.88>\mathrm{h} / \mathrm{a}=1.30 \\
& \mathrm{~d} / \mathrm{b}=1.81>\mathrm{i} / \mathrm{a}=1.50 \\
& \mathrm{f} / \mathrm{e}=1.92>\mathrm{h} / \mathrm{a}=1.30 \\
& \mathrm{~g} / \mathrm{e}=2.31>\mathrm{i} / \mathrm{a}=1.50
\end{aligned}
$$

この比較結果から有機ベントナイトの増粘作用はドライ ヤーによってなんら低下していないことが認められる。

\section{2 コンシステンシーに及ぼす影響}

塗料 $\mathrm{A}$ 扣よび塗料 $\mathrm{B}$ の調製 1 日後の $\mathrm{KU}$ 捛よび粘度を 表-6 に示す。また塗料 B の経時变化の 测定結果を表-7 飞示す。

流れ止剤配合率に応ずる $\mathrm{KU}$ 扔よび粘度の変化を図-3 牤よび図-4 亿示す。塗料 A $\mathrm{KU}$ は流れ止剂の添加に よる影響が少なく，有機ベントナイトが $0.8 \%$ 以上配合 された場合にはじめて増大が認められる。しかし粘度は 流れ止め剤の添加によって泳湆直線的に增大し, そのコ ウ配は各流れ止剤の増粘作用の強さを現わするのと考光 られる。塗料 Bの固形分和よび PVC は塗料Aのそれよ りも高いのでブランクの KU 呿よび粘度は塗料 $\mathrm{A}$ よりも 著しく高い值を示して特り，各流れ止剂配合により $\mathrm{KU}$ にも顕著な変化が現われている。そして有機ベントナイ ト（II）を除いて他の流れ止剂配合塗料の KU おるび粘度

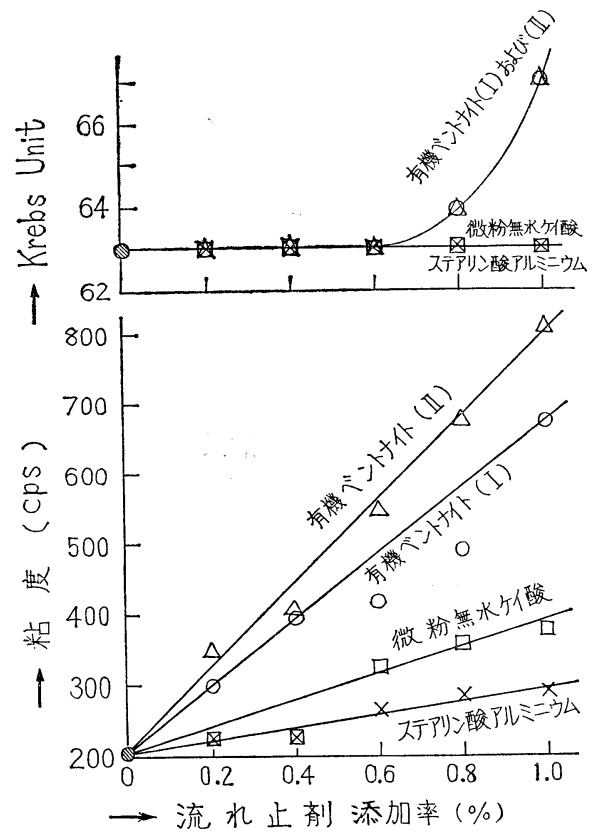

図-3 塗料(A)のコンシステンシーに及ぼす各種流 れ止剂の影響
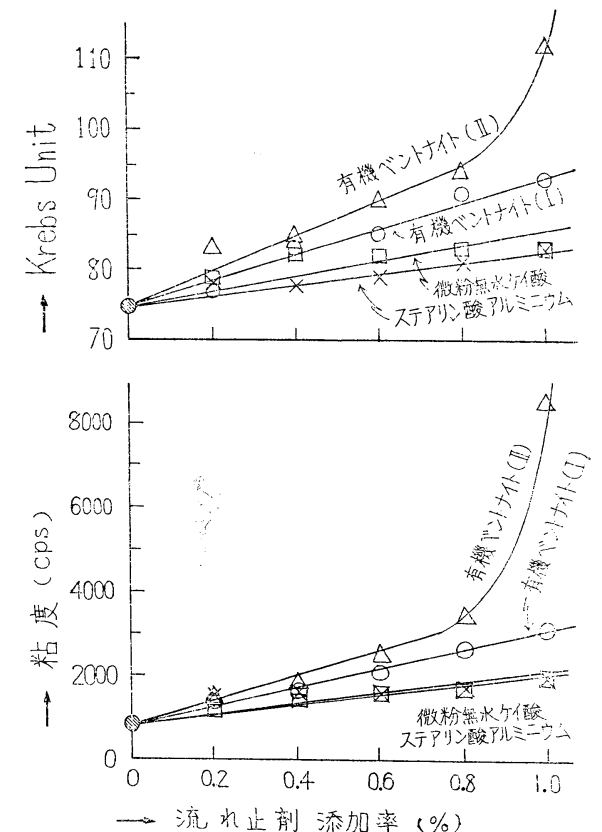

図-4 塗料 (B)のコンシステンシーに及ぼす各種流 れ止剤の影響

は配合率の増加と共に直線的に增大している。有機ベン トナイト(II)の場合は $0.8 \%$ 配合をでは $\mathrm{KU}$ および粘度 とも直線的で岕るが $1.0 \%$ 配合では急激な上昇が現われ ている。図-3 特よび図-4 の粘度のプロットから直線部 分の大略のコウ配を求め流れ止剤の增粘作用の強さを比 較すると表-8 のと扮りである。固形分濃度の低い塗料 $\mathrm{A}$ では有機ベントナイトの增粘作用はステアリン酸アル ミニウムの 5 〜 倍という高い值となるにるかかわらず, $0.6 \%$ 以下の配合率では KUにほとんど変化を与兄てい ないことは，塗料のハケ別きを重くすることなく微小な セン断速度での粘度を高めることになり, 後で述べるタ ルミの防止として有効作用するものと考光られる。ま

\begin{tabular}{|c|c|c|c|c|}
\hline \multirow[b]{2}{*}{ 流れ止剂の種 類 } & \multicolumn{2}{|c|}{ 塗 料 $\mathrm{A}$} & \multicolumn{2}{|c|}{ 塗 料 B } \\
\hline & $\begin{array}{l}\text { コウ配 } \\
\operatorname{cps} / \%\end{array}$ & $\begin{array}{l}\text { コウ* } \\
\text { 配相 } \\
\text { 対值 }\end{array}$ & $\begin{array}{l}\text { 二ウ配 } \\
\operatorname{cps} / \%\end{array}$ & $\begin{array}{l}\text { コウ* } \\
\text { 配相 } \\
\text { 対値 } \\
\end{array}$ \\
\hline 有機ベントナイト（I） & 473 & 5.5 & 2,340 & 1.7 \\
\hline 有機ベントナイト（II） & 602 & 6.9 & 3,040 & 2.2 \\
\hline 微粉 無 水ヶイ 酸 & 186 & 2.1 & 1,340 & 1.0 \\
\hline ステアリン酸アルミニウム & 87 & 1.0 & 1,370 & 1.0 \\
\hline
\end{tabular}
た固形分濃度の高い塗料 $\mathrm{B}$ はいずれる $\mathrm{KU}$ が 75 以上で, ハケ別きに適するコンシステンシーとしては KU が 70 以下に希釈されて用いられる苜から，そのような固形分

表-8 流れ止剂の増粘作用の比較

*ステアリン酸アルミニウムのコウ配を 1.0 とする。 


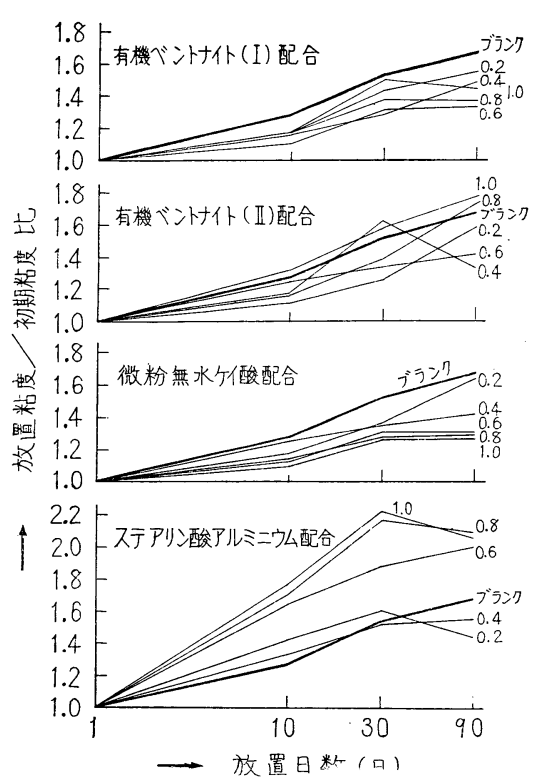

図 5 塗料 (B)のコンシステンシー経時 変化に及ぼす各種流れ止剤の影響

濃度では塗料 Aに扣いて認められた有機ベントナイトの コンシステンシーに及ぼす特徵が後述するように KUを 一定にした場合の見掛け粘度の増大として顕著に現われ てくることになる。

塗料 Bについて放置粘度/初期粘度比と放置日数との 関係を図-5 に示す。この図から有機ベントナイト配合 塗料の粘度経時変化は流れ止剤無配合塗料よりも低目な いし同程度と考えてよいであろう。微粉無水ケイ酸もま た粘度の経時変化を小さくしているが，ステアリン酸ア ルミニウム配合塗料の粘度経時変化は著しい増大を示す 傾向のあることが認められる。

\section{3 タルミに及ぼす影響}

塗料 $\mathrm{A}$ についてはその KUから判断して調製した塗料 そのままを用い, 塗料 Bについてはミネラルスピリット を加えて KUをほぼ 70 に希釈したのちタルミ測定を行 なった。測定結果を表-9 に示す。各流れ止剤添加率と タルミとの関係を示すと図-6 扝よび図-7 のと扣りであ る。な和データに幾分バラッキが認められるのはアプリ ケーターで得られる塗膜厚みにバラッキができるためで あらう。

図-6 特よび図-7 から有機ベントナイトのタルミ防止 作用は他の流れ止剂に比べて強力であることが認められ る。とくに PVC が高く密度の大きい塗料 Bに蛒いては 微粉無水ケイ酸のタルミ防止効果は認められない。粘度 の対数 $(\log \eta)$ とタルミとの関係をプロットしてみると 図-8 特よび図-9 のようになり直線的な関係が現われる

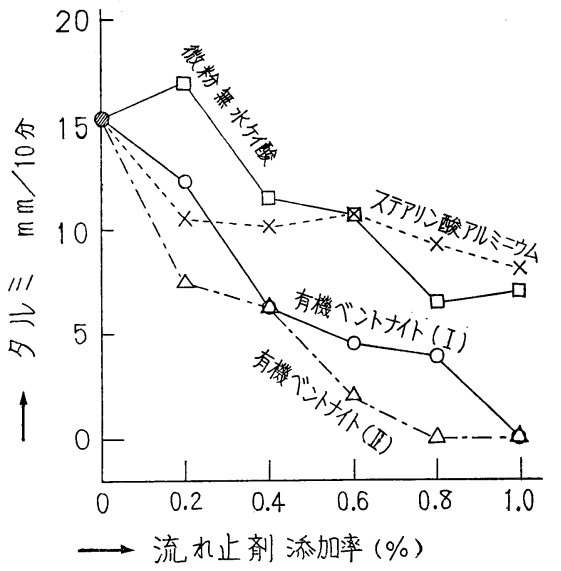

図-6 塗料 $(\mathrm{A})$ ) タルミに及ぼす各種流れ止剤の影響

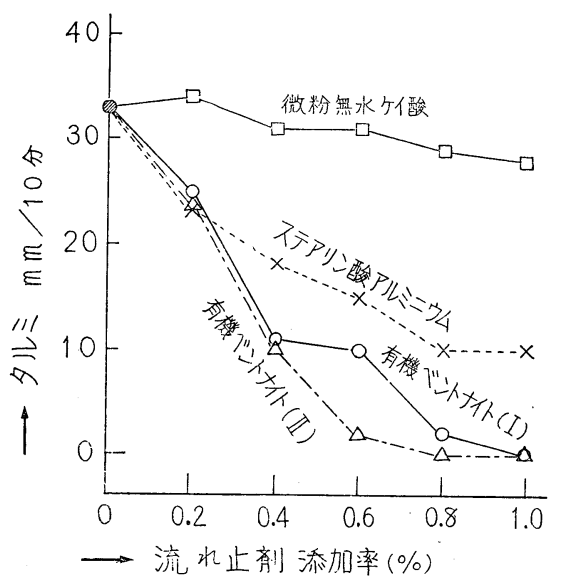

図-7 塗料の (B) タルミに及ぼす各種流れ止剤の影響 ことは，タルミは粘度の函数であることを示すものであ るが, 興味あることは塗料 Bについての $\log \eta$ タルミ関 係を示す 図-9 では流れ止剤別に直線が別れていること である。このことは同一粘度に执いても流れ止剤によっ てタルミ防止効果が異なることを示し，有機ベントナイ ト>ステアリン酸アルミニウム>微粉無水ケイ酸の順に 効果が小さくなっている。この解釈としては, 有機ベン トナイトの粒子はきわめて薄い板状であるため塗膜をつ くる際に膜面と平行な方向に板状粒子が配列7) し，乙か も積み重なった板状結晶層間に挌けるビヒクルとの溶媒 和によって膜面方向のずれを拘束する作用が強く現われ てくる。一方，ステアリン酸アルミニウムについては緎 維状集合体が想定されて特り ${ }^{8)}$ ，その繊維はやはり膜面 方向に配向するでめろ $3^{9}$ が，有機ベントナイトの平面 的な構造に比べて線状であるため膜面方向のずれを拘束 する作用は弱いと考えられる。微粉無水ケイ酸の場合は 
表-9 塗料のタルミに及ぼす各種流れ止剤の影響

\begin{tabular}{|c|c|c|c|c|c|c|}
\hline \multirow{2}{*}{\multicolumn{2}{|c|}{ 流れ止剤配合率 \% }} & \multirow{2}{*}{\begin{tabular}{|l|} 
塗料 $\mathrm{A}$ \\
タル \\
$\mathrm{mm/}$ \\
10 分
\end{tabular}} & \multicolumn{2}{|c|}{ 荼 } & \multicolumn{2}{|l|}{ 料 $\mathrm{B}$} \\
\hline & & & $\begin{array}{l}\text { タルミ } \\
\mathrm{mm} / \\
10 \text { 分 }\end{array}$ & $\mathrm{KU}$ & $\begin{array}{l}\text { 粘 度 } \\
\mathrm{cps}\end{array}$ & $\begin{array}{l}\mid \text { 溶剤添 } \\
\text { g/500g }\end{array}$ \\
\hline \multicolumn{2}{|c|}{$\begin{array}{l}\text { ブランク (流れ止 } \\
\text { 郕無配合) }\end{array}$} & 15.2 & 33.0 & 71 & 750 & 25 \\
\hline \multirow{5}{*}{$\begin{array}{l}\text { 有機ベントナ } \\
\text { イト(I) }\end{array}$} & 0.2 & 12.2 & 26.0 & 72 & 1,000 & 30 \\
\hline & 0.4 & 6.2 & 11.2 & 70 & 1,100 & 30 \\
\hline & 0.6 & 4.5 & 10.0 & 70 & 1,100 & 35 \\
\hline & 0.8 & 3.9 & 2.2 & 70 & 1,100 & 40 \\
\hline & (1.0 & 0 & 0 & 70 & 1,340 & 50 \\
\hline \multirow{5}{*}{$\begin{array}{l}\text { 有機ベントナ } \\
\text { 个(II) }\end{array}$} & 10.2 & 7.5 & 23.7 & 69 & 875 & 30 \\
\hline & 0.4 & 6.2 & 10.0 & 70 & 1,300 & 35 \\
\hline & 0.6 & 2.0 & 2.0 & 70 & 1,300 & 40 \\
\hline & 0.8 & 0 & 0 & 70 & 1,480 & 45 \\
\hline & 1.0 & 0 & 0 & 70 & 1,840 & 70 \\
\hline \multirow{5}{*}{ 徵粉無水ケイ } & 0.2 & 17.0 & 34.0 & 69 & 750 & 25 \\
\hline & 0.4 & 11.5 & 31.0 & 69 & 880 & 30 \\
\hline & $\{0.6$ & 10.7 & 31.0 & 69 & 950 & 30 \\
\hline & 0.8 & 6.5 & 29.0 & 70 & 1,000 & 30 \\
\hline & 1.0 & 7.5 & 28.0 & 70 & 1,160 & 30 \\
\hline \multirow{5}{*}{$\begin{array}{l}\text { ステアリン酸 } \\
\text { アルミニウム }\end{array}$} & 0.2 & 10.5 & 23.0 & 68 & 1,140 & 30 \\
\hline & 0.4 & 10.1 & 18.0 & 68 & 1,140 & 30 \\
\hline & $\{0.6$ & 10.7 & 15.0 & 68 & 1,340 & 35 \\
\hline & 0.8 & 9.2 & 10.0 & 68 & 1,340 & 40 \\
\hline & (1.0 & 8.0 & 10.0 & 68 & 1,420 & 45 \\
\hline
\end{tabular}

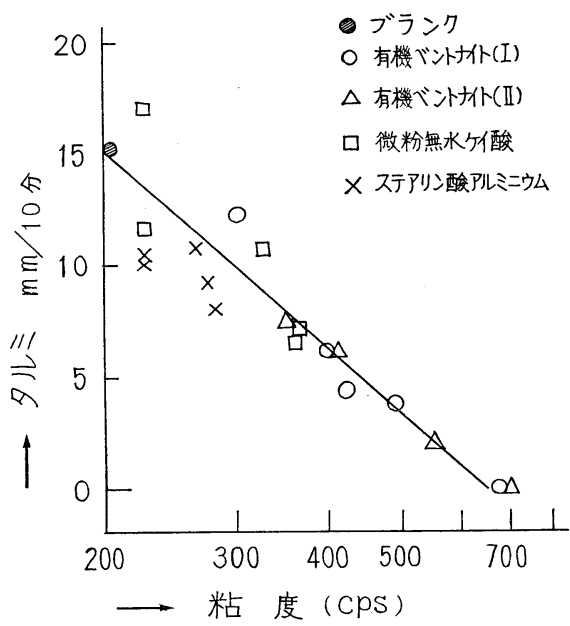

図-8 塗料 $(\mathrm{A})$ の $\log \eta$-タルミ関係

球状粒子であるから前者のような粒子の配列効果はかな り小さくなり，タルミ防止効果が最も弱く現われている ものと推定される。

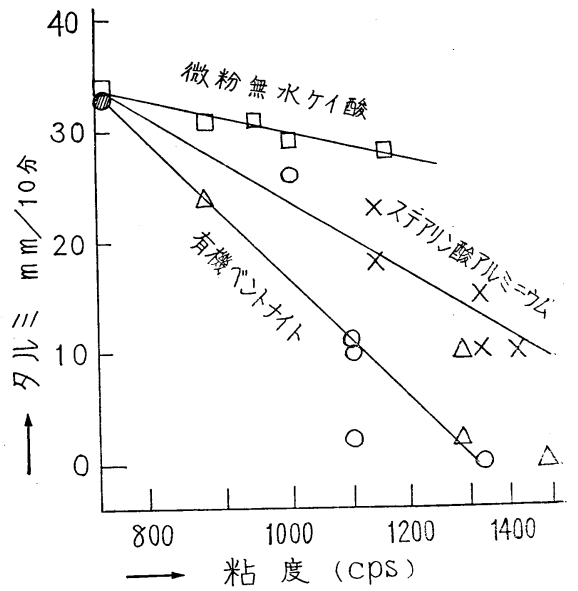

図-9 塗料 $(\mathrm{B})$ の $\log \eta$ ータルミ関係

\section{4 顔料の沈降に及ばす影響}

塗料 $\mathrm{A}$ 和よび塗料 Bの 90 日貯蔵後の顔料沈降容積貺? 定結果を表-10 亿示す。流れ止剤配合率と颜料沈降容積 沈降容積測定結果(90日)

\begin{tabular}{|c|c|c|c|}
\hline \multicolumn{2}{|c|}{$\begin{array}{l}\text { 流れ止剤配 } \\
\text { 合率 } \%\end{array}$} & \multicolumn{2}{|c|}{\begin{tabular}{|l|l|} 
滁料 $\mathrm{A}$ & 塗料 $\mathrm{B}$ \\
$\mathrm{cc} /$ & $\mathrm{cc} /$ \\
$500 \mathrm{cc}$ & $500 \mathrm{cc}$ \\
\end{tabular}} \\
\hline $\begin{array}{l}\text { ブランン } \\
(\text { 流れ止斉 } \\
\text { 無配合 }\end{array}$ & 剂) & $\begin{array}{l}\text { 境界* } \\
\text { 不明 }\end{array}$ & $452^{*}$ \\
\hline \multirow{5}{*}{$\begin{array}{l}\text { 有機ベン } \\
\text { トナイト } \\
(\mathrm{I})\end{array}$} & 0.2 & 205 & 428 \\
\hline & 0.4 & 251 & 437 \\
\hline & 0.6 & 296 & 459 \\
\hline & 0.8 & 305 & 450 \\
\hline & 1.0 & 410 & 456 \\
\hline \multirow{5}{*}{$\begin{array}{l}\text { 有機ベン } \\
\text { トナイト } \\
\text { (II) }\end{array}$} & 0.2 & 228 & 425 \\
\hline & 0.4 & 296 & 478 \\
\hline & $\{0.6$ & 328 & 484 \\
\hline & 0.8 & 374 & 488 \\
\hline & 1.0 & 455 & 490 \\
\hline \multirow{5}{*}{$\begin{array}{l}\text { 微粉無水 } \\
\text { ケイ酸 }\end{array}$} & 0.2 & 228 & 431 \\
\hline & 0.4 & 205 & 425 \\
\hline & $\{0.6$ & 230 & 412 \\
\hline & 0.8 & 230 & 420 \\
\hline & 1.0 & 230 & 453 \\
\hline \multirow{5}{*}{$\begin{array}{l}\text { ステアリ } \\
\text { ン酸アル } \\
\text { ミ゙ウ }\end{array}$} & 0.2 & 228 & 392 \\
\hline & 0.4 & 228 & 396 \\
\hline & $\{0.6$ & 251 & 396 \\
\hline & 0.8 & 251 & 426 \\
\hline & (1.0 & 296 & 437 \\
\hline
\end{tabular}

*底部にケーキを認めた。
表-10 塗料中に和ける 顔料 との関係をプロットする と図-10 特よび図-11 の と和りである。これらの 結果から有機ベントナイ トが最も優れた顔料沈降 防止作用を示しているこ とは，築坂 2 らの希薄な 溶液系について認められ た傾向と同じである。と くに本実験結果で注目す べきことは流れ止剤の添: 加によって沈降容積に極 小値が現われることで, 図-10 の塗料Aについて は流れ止剤 $0.2 \%$ からプ ロットしてあるため不明 りょうであるが，流れ止 剂無配合の場合は最上層 まで懸濁しているので有 機ベントナイトについて は $0.2 \%$ ，ステアリン酸 アルミニウムについては $0.2 \sim 0.4 \%$, 微粉無水ケ イ酸については $0.4 \%$ の 付近が沈降容積の極小点 となっている。図-11 の 塗料 Bについてはこの傾. 


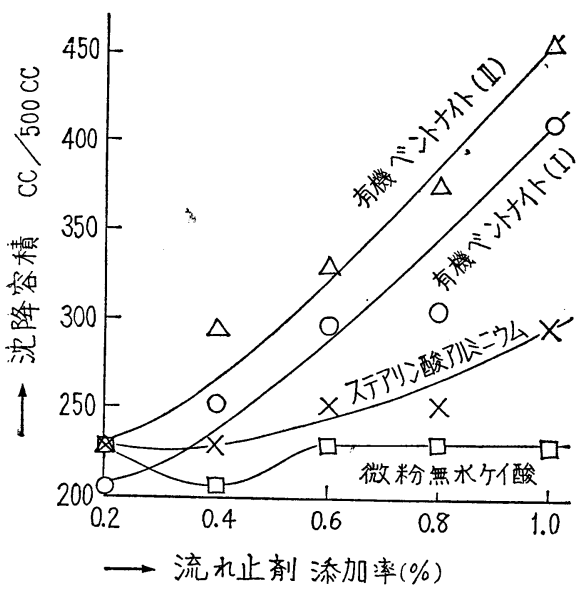

図-10 塗料 (A)の顔料沈降容積 (90日)

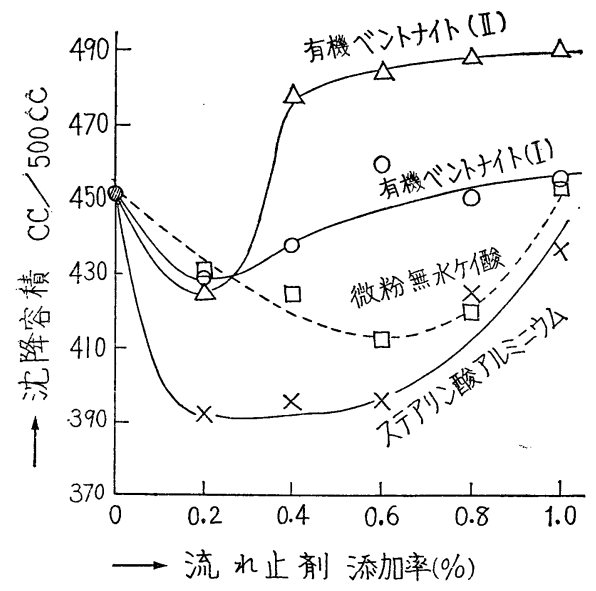

図-11 塗料 (B) の顔料沈降容積 (90日)

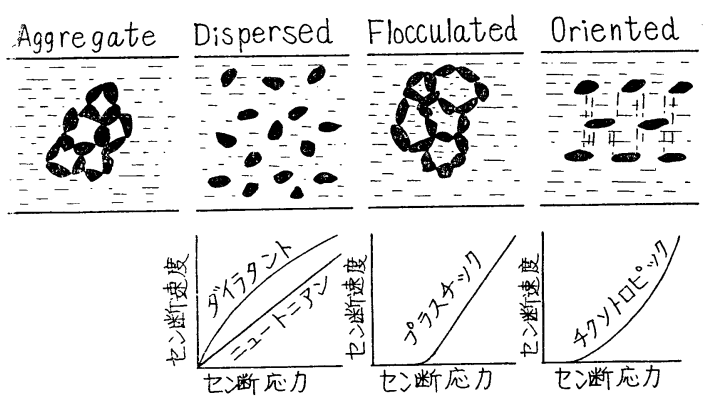

図-12 顔料の分散状態と塗料の性質

向が顕著に認められ，有機ベントナイトが $0.2 \%$ の付近 て幅せをい極小ピークを示し，次いで添加量の増大とと もに沈降容積が増大しているのに比べ，微粉無水ケイ酸 およびステアリン酸アルミニウムは幅広い極小ピークを 示している。図-12 は一般に想定されている顔料の分散
状態と塗料の性質のモデル10,11)であるが，まず流れ止剂 無添加の場合は dispersed 形の分散状態に近いと考えら れる。これに流れ止剂が添加されるとある添加率に達す るまでは分散顔料粒子に作用してフロキュレーションを 生じさせソフトケーキを形成する。さらに添加量が増加 すると流れ止剤の溶媒和構造がビヒクル中に十分発達し てくるので顔料粒子のフロニキレーションに対して妨害 的な役割を演じ，より一層再分散しやすい膨潤した顔料 層をつくるようになるものと考えられる。そして流れ止 剂を応用する場合は顔料沈降容積の極小点を越光る添加 量を用いることが望ましく，有機ベントナイトが微粉無 水ケイ酸やステアリン酸アルミニウムに比較して沈降容 積の極小を示す添加率が極く低いところにあること，極 小点に和ける沈降容積が大きいこと, 牤よび沈降容積の 極小点からの立ち上りが顕著であるから，再分散しきす い膨潤した顔料沈殿層をつくる効果が大きく顔料沈降防 止剂としての作用もすぐれていることがうかがえる。

\section{5 乾燥塗膜の耐届曲性に及ぼす影響}

表-11 乾燥塗膜の耐屈曲性試験結果

\begin{tabular}{|c|c|c|c|c|c|}
\hline \multirow{2}{*}{\multicolumn{2}{|c|}{$\begin{array}{c}\text { 折り曲げ } \\
\text { 直径 } \\
\text { 流れ止剂 } \\
\text { 配合率\% }\end{array}$}} & \multicolumn{2}{|c|}{ 塗 料 A } & \multicolumn{2}{|c|}{ 塗 料 B } \\
\hline & & $3 \mathrm{~mm}$ & $2 \mathrm{~mm}$ & $8 \mathrm{~mm}$ & $6 \mathrm{~mm}$ \\
\hline $\begin{array}{l}\text { ブランク } \\
\text { 止剤無配合 }\end{array}$ & 流れ & 0 & 0 & ++ & ++ \\
\hline \multirow{5}{*}{$\begin{array}{l}\text { 有機ベント } \\
\text { ナイト(I) }\end{array}$} & 0.2 & 0 & 0 & 0 & ++ \\
\hline & 0.4 & 0 & 0 & + & ++ \\
\hline & $\{0.6$ & 0 & 0 & + & ++ \\
\hline & 0.8 & 0 & 0 & 0 & ++ \\
\hline & 1.0 & 0 & $\bigcirc$ & + & + \\
\hline \multirow{5}{*}{$\begin{array}{l}\text { 有機ベント } \\
\text { ナイト(II) }\end{array}$} & 0.2 & 0 & $\bigcirc$ & 0 & + \\
\hline & 0.4 & 0 & $\bigcirc$ & 0 & ++ \\
\hline & 0.6 & 0 & 0 & + & + \\
\hline & 0.8 & 0 & 0 & + & ++ \\
\hline & 1.0 & 0 & 0 & $\bigcirc$ & ++ \\
\hline \multirow{5}{*}{$\begin{array}{l}\text { 微粉無水ケ } \\
\text { イ酸 }\end{array}$} & 0.2 & 0 & 0 & + & ++ \\
\hline & 0.4 & 0 & 0 & + & ++ \\
\hline & 0.6 & 0 & $\bigcirc$ & + & ++ \\
\hline & 0.8 & $\bigcirc$ & + & + & ++ \\
\hline & 1.0 & $\bigcirc$ & + & + & ++ \\
\hline \multirow{5}{*}{$\begin{array}{l}\text { ステアリン } \\
\text { 酸アルミ } \\
\text { ウム }\end{array}$} & 0.2 & $\bigcirc$ & $\bigcirc$ & ++ & ++ \\
\hline & 0.4 & $\bigcirc$ & 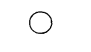 & ++ & ++ \\
\hline & 0.6 & 0 & + & ++ & ++ \\
\hline & 0.8 & 0 & + & ++ & ++ \\
\hline & 1.0 & $\bigcirc$ & + & ++ & ++ \\
\hline
\end{tabular}

○：ワレを認めず，十：ごくわずかにワレを認む， ++ ：明らかにワレを認む。 
塗料 $\mathrm{A}$ 牥よび塗料 $\mathrm{B}$ の乾燥塗膜の機械的強度に及ぼす 洛種流孔止剤の影響を調べるため耐屈曲性てついて試験 した結果を表-11 に示す。この結果からこれら流れ止剤 の耐屈曲性に及ぼす影響は配合量が少ないため明確な変 化は認めにくいが，有機ベントナイト配合塗膜は無配合 塗膜よりもわずかに良好な結果が得られていることは, タルミ試験で想定した板状結晶粒子の膜面方向の配列に 基づく効果が寄与しているのであろう。ステアリン酸ア ルミニウムの場合, 無配合のものよりも幾分低目の結果 となっているのは，本試験法が $120^{\circ} \mathrm{C} て ゙ 1$ 時間加熱した 塗膜について折り曲げるため，ステアリン酸アルミニウ ムの融点以上に加熱処理されることに劣化原因があるの ではないかと考えられる。

\section{6 促進耐候試験結果}

塗料 Aについて促進耐候試験 1,000 時間を実施した結 果, いずれの流れ止剤配合塗膜についても肉眼観察では ワレ, フクレ, ハガレ, サビは認められず優劣の判定は 困離であった。（本研究は昭 38.11.20，色材協会，日本 化学会共摧, 1963 年度関西支部研究発表会にて発表し た。)

\section{文献}

1）長谷川, 近藤 : 工化, 61，1243 6 (1958)

2) 築坂, 相沢 : 色材, 36, 217 224 (1963)

3) Gardner, H.A. and G.G.Sward, Physical and Chemical Examination Paints, varnishes, Lacquers and Colors, 12, 113, Gardner Laboratory (1962)

4) 同上, $178 \sim 179$.

5）同上, 201 .

6) Gordon, P.L. and R.Gordon, Paint and Varnish Manual Formulation and Testing, 141, Interscience Publishers (1955)

7) 井上 : 工化, 59, 124 127 (1956)

8) Payne, H.F., Organic Coating Technology II, Pigments and Pigmented Coatings, 939, John Wiley \& Sons (1961)

9）小口, 鈴木 : 油化学, 7, 474 481 (1958)

10) Payne, H.F., Organic Coating Technology II. Pigments and Pigmented Coatings, 732, John Wiley \& Sons (1961)

11) Ensminger, R.I., Official Digest, 35, 72 (1963)

\section{色 材協 会 誌 37 巻 5 号 (子告)}

報文

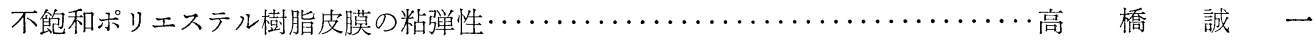
(大日本インキ化学工業(株))

メタクリル酸, グリシジルのホモポリマーおよびュポリマーの熱硬化反応

野 間 夫之, 四十宮竜德 他 2 名 (京都大学, 高分子化学工業(株))

塗料用ポリエステル樹脂に関する研究(第 9 報)：………野 間 夫 之, 四十宮竜徳 (京都大学, 高分子化学工業(株))

資 料

溶解パラメーターの意味

黒 謙 次 郎 (東京理科大学)

実験ノート

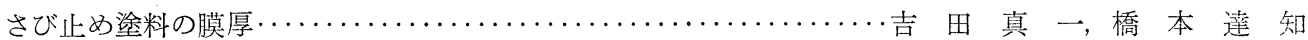
(鉄道技術研究所)

\section{技術ノート}

電気を使わない液面，容量，濃度などの制御………………… 鈴 一 (鈴木成一事務所)

文献 